\title{
Application of sequence stratigraphy for an enhanced hydrocarbon reservoirs correlation in "OSP" field Niger Delta, Nigeria
}

\author{
Oluwaseye Peter Oyetade ${ }^{1}\left[\right.$. Suyi Lawrence Fadiya ${ }^{2} \cdot$ Olatunbosun. A. Alao $^{2}$
}

Received: 4 October 2019 / Accepted: 13 July 2020 / Published online: 18 July 2020

(c) The Author(s) 2020

\begin{abstract}
The cost of drilling exploration and production wells is high and the price of crude oil in the capital market is fluctuating, therefore, there is the need to mitigate the risk of improper investigation of time/age-dependent reservoir rocks continuity within a field. Sequence stratigraphic analysis was carried out in $O S P$ field with the aim of identifying and correlating hydrocarbon reservoirs that are deposited contemporaneously. Key stratigraphic surfaces (maximum flooding surfaces and sequence boundaries) were interpreted from biostratigraphic, well log and seismic data. Biostratigraphic interpretation subdivide the study area into three floral subzones-P780, P820 and P830. Three maximum flooding surfaces dated 10.4 Ma, 9.5 Ma and 7.4 Ma and four sequence boundaries dated 10.6 Ma, 10.35 Ma, 8.5 Ma and 6.7 Ma were identified. Three depositional sequences (sequences 1-3) were identified from the integration of the biostratigraphic, well log and seismic data. The identified key stratigraphic surfaces and depositional sequences were employed in the delineation and correlation of the hydrocarbon reservoirs which were found to fall within the highstand and lowstand systems tracts. Sequence stratigraphic correlation technique aided the local arrangement and geometries of reservoirs within the field and in locating potential reservoirs.
\end{abstract}

Keywords Biostratigraphic $\cdot$ Chronostratigraphic surface $\cdot$ Contemporaneously $\cdot$ Maximum flooding surfaces $\cdot$ Sequence boundaries

\section{Introduction}

A successful drilling campaign in the oil and gas industry is achieved when hydrocarbon is successfully explored from the subsurface to the surface as predicted by the geoscientist. However, a number of dry holes have been drilled by oil companies and some reservoirs bypassed due to pit falls in interpretation procedures of some geology principles. An example of such principle is proper well correlation to establish lateral extent and interconnectivity of hydrocarbon reservoirs that are time related.

Correlation is the process of identifying the time relationships between different rock units by which we identify which ones are older, which are younger and which are

Oluwaseye Peter Oyetade

oyetadeoluwaseye@gmail.com

1 Department of Geology, University of Calabar, Calabar, Nigeria

2 Department of Geology, Obafemi Awolowo University, Ile-Ife, Nigeria of the same age (Nichols 2009). Correlation is therefore a useful guiding principle in identifying, establishing the lateral extent and interconnectivity hydrocarbon reservoir rocks within or across fields. According to Nichols (2009), lithostratigraphic correlation is the process of establishing rock relationships in terms of lithological characteristics of a strata and its relative stratigraphic positions. The relative stratigraphic positions of a rock unit can be determined by considering the geometric and physical relationships that indicate which beds are older and which ones are younger.

In recent years, the geophysical properties of strata have become very important in correlation, particularly in the subsurface. Well-logging uses physical properties of the rock that can be detected by devices pulled through drill holes and it is the primary tool for modern subsurface correlation (Prothero and Schwab 2014). Well log-based correlation is therefore similar to lithostratigraphic correlation. Wireline log/well log (gamma ray, resistivity, sonic, density and neutron) correlation in stratigarphically and structurally complex settings, such as many oil and gas fields, may not be reliable without sufficient coring and special logging 
in addition to well testing (Slatt et al. 1992). Therefore, to increase the efficiency and cost-effectiveness of exploration in more complex fields, several old techniques have been updated and new ones introduced, such as sequence stratigraphy. Sequence stratigraphy is a multidisciplinary approach to the study of rock relationships within a chronostratigraphic framework of repetitive, genetically related strata bounded by surfaces of erosion or non-deposition or their correlative conformities (Van Wagoner et al. 1988). This approach subdivides a stratigraphic section into packages of sediments (sequences) bounded by chronostratigraphically significant surfaces (maximum flooding surfaces and sequence boundaries).

In this study, we carried out a sequence stratigraphic analysis by integrating biostratigrahic, well log and seismic data for the purpose of providing an enhance method of identifying and correlating possible hydrocarbon sand units that are deposited contemporaneously, to mitigate reservoir bypass and thus increasing revenue.

\section{Geology of the Niger Delta}

The Niger Delta lies mainly in the Gulf of Guinea to the southwest of the Benue Trough and constitutes the most important Cenozoic construction in the South Atlantic. It is located in the southern part of Nigeria between latitudes $4^{\circ}$ and $6^{\circ} \mathrm{N}$ and longitudes $3^{\circ}$ and $9^{\circ} \mathrm{E}$ (Nwachukwu and Chukwura 1986). It is bounded in the south by the Gulf of Guinea and in the North by older Cretaceous elements such as the Anambra Basin, Abakaliki uplift and Afipko syncline
(Fig. 1a). The Niger Delta covers a land area in excess of $105,000 \mathrm{~km}^{2}$ (Avbovbo 1978) and it extends in an East-West direction from southwestern Cameroun to the Okitipupa Ridge. Its apex is situated southeast of the confluence of the Niger and Benue Rivers. The study field is located within the coastal swamp depobelt portion of the basin (Fig. 1b).

\section{Stratigraphy and structure of the Niger Delta}

The Niger Delta Basin consists of three main lithostratigraphic units (Fig. 2) of Cretaceous to Holocene age (Short and Stauble 1967; Avbovbo 1978; Reijers 2011). These are the Akata, Agbada, and Benin Formations. The Niger Delta is a regressive sequence of clastic sediment developed in a series of offlap cycles (Reijers 2011). It is believed that the shale of Akata Formation is the source rock for hydrocarbon in the Niger Delta (Ekweozor and Daukoru 1994). The base of the sequence consists of massive and monotonous marine shales which grade upward into interbedded shallow-marine and fluvial sands, silts and clays representing a typical paralic facies of the Agbada Formation. The uppermost part of the sequence (Benin Formation) is a massive non-marine section (Doust and Omatsola 1990), which represents the sediments of the marine, transitional and continental environments as would be expected of an advancing delta such as that of River Niger (Short and Stauble 1967).

The Niger Delta has been subdivided into five zones, each of which is characterized by different structural styles. Corredor et al. (2005) made the following description of the structural styles of the Niger Delta (Fig. 3). (1) an extensional region beneath the continental shelf that is

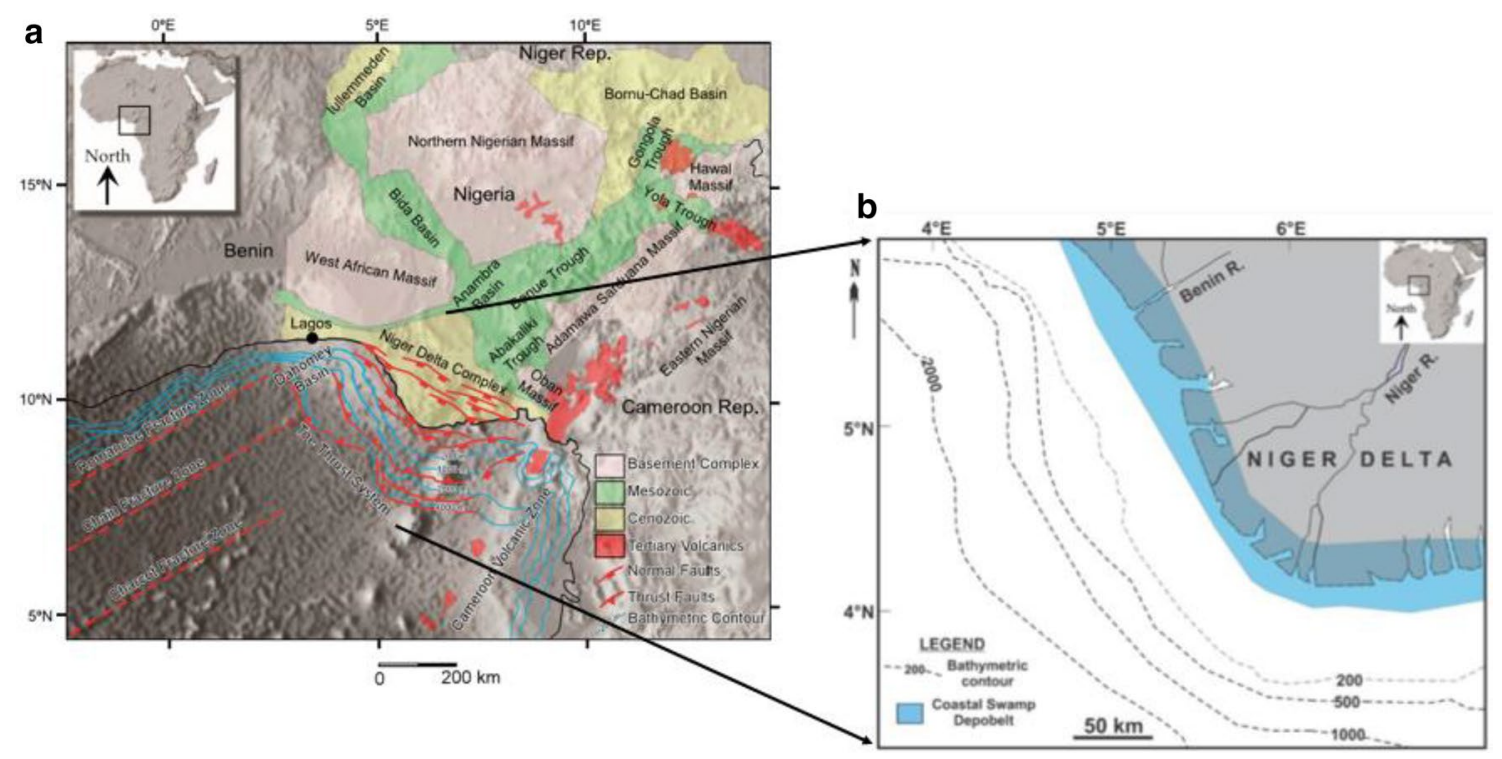

Fig. 1 Map showing a the Niger Delta Basin and other Nigerian sedimentary basins (Corredor et al. 2005). b Location of the study within the coastal swamp depobelt. Modified after Deptuck et al. (2003). 


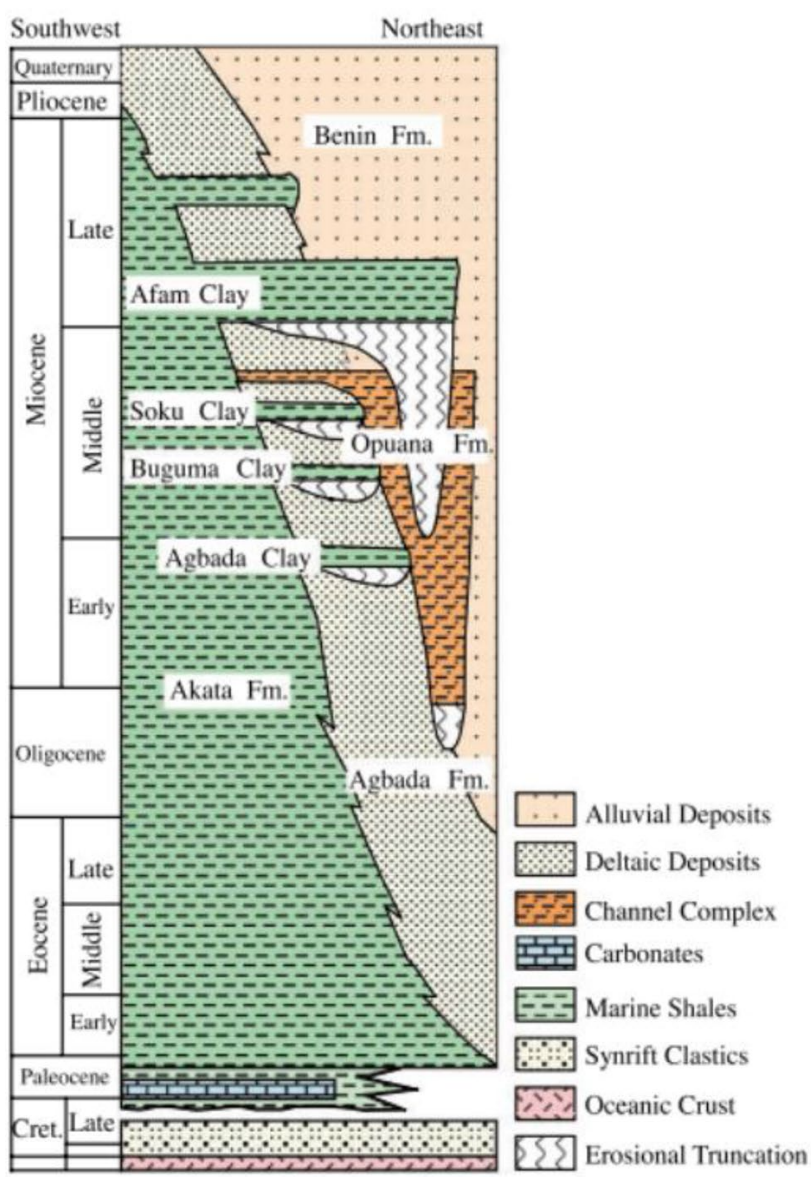

Fig. 2 Schematic diagram of the regional stratigraphy of the Niger Delta (Corredor et al. 2005)

characterized by both basinward-dipping (Roho-type) and counter regional growth normal faults as well as associated rollovers and depocenters; (2) by passive, active, and reactive mud diapirs, including shale ridges and massifs, shale overhangs, vertical mud diapirs that form mud volcanoes at the seafloor and interdiapir depocenters characterized the upper continental slope; (3) basinward-verging thrust faults (typically imbricated) and associated folds, including some detachment folds characterized the inner fold and thrust; (4) a transitional detachment fold zone beneath the lower continental slope that is characterized by large areas of little or no deformation interspersed with large, broad detachment folds above structurally thickened Akata Formation; and (5) the outer fold and thrust belt characterized by both basinward- and hinterland-verging thrust faults and associated folds.

\section{Material and methods}

Materials used for this study were obtained from Department of Petroleum Resources, Nigeria. The biostratigraphic data provided for this research contains microfossil counts (abundance and diversity), depth values, identified index fossil and zones, as well as a suite of well logs and 3D seismic data. The field is code named "OSP" and the wells $\log$ (log data in LAS format) are also named; OSP-001, OSP-002, OSP-010, and OSP-013 for proprietary reasons. Table 1 shows a summary of the available data set for this study. The base map of the study area and their respective well locations are shown in Fig. 4. OSP001 and OSP-002 are the only wells with biostratigraphic information.

Reservoir sands identification was done using the log signatures of both gamma ray (GR) and deep resistivity logs. Zones with low gamma ray log read and high resistivity readings were considered as hydrocarbon bearing sand unit while zones with low resistivity readings and low gamma ray $\log$ reading were considered as water-bearing sand units.

Biostratigraphic, well log and seismic data were integrated to carry out the sequence stratigraphic analysis. Vail's sequence stratigraphic model (Vail et al. 1977; Vail 1987) was employed in recognizing stratigraphic sequences and systems tract boundaries as discontinuity surfaces or their correlative conformities that bound stacks of strata in the study area.

The diagnostic markers from the biostratigraphic data were used in the zonation of the studied wells. The ages derived from the identified zones (palynological and foraminifera) have been documented in the literature by Evamy et al. (1978) and these were used in determining the ages of the key stratigraphic surfaces (sequence boundaries (SBs) and maximum flooding surfaces (MFSs). The identified key stratigraphic surfaces were then correlated to the Niger Delta chronostratigraphic chart of Haq et al. (1988) (Fig. 5). The MFSs were identified as the microfaunal horizon with the highest diversity and abundance of microfossil assemblage while the SBs were identified at intervals of low to no microfossil count.

The key stratigraphic surfaces identified from the biostratigraphic data and vertical patterns of facies from gamma ray (GR) log (Vail 1987) (Fig. 6) aided the identification of these MFS and SB on the GR log. Systems tracts (Lowstand systems tract (LST), Transgressive systems tract (TST) and Highstand systems tract (HST) and depositional sequences were recognized from the gamma ray $\log$ motif using the nature of their boundaries and their internal geometry as proposed by Vail (1987) (Fig. 6).

The recognized and identified constrained chronostratigraphic surfaces (maximum flooding surfaces (MFSs) and

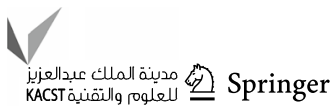




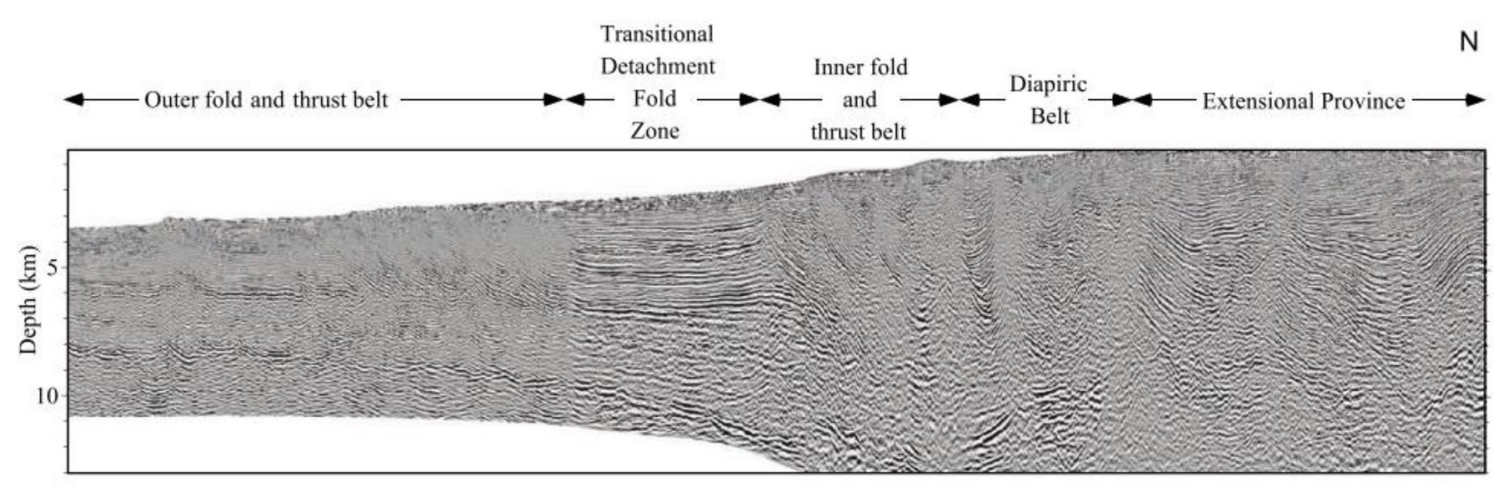

$\stackrel{10 \quad 20}{0} \mathrm{~km}$

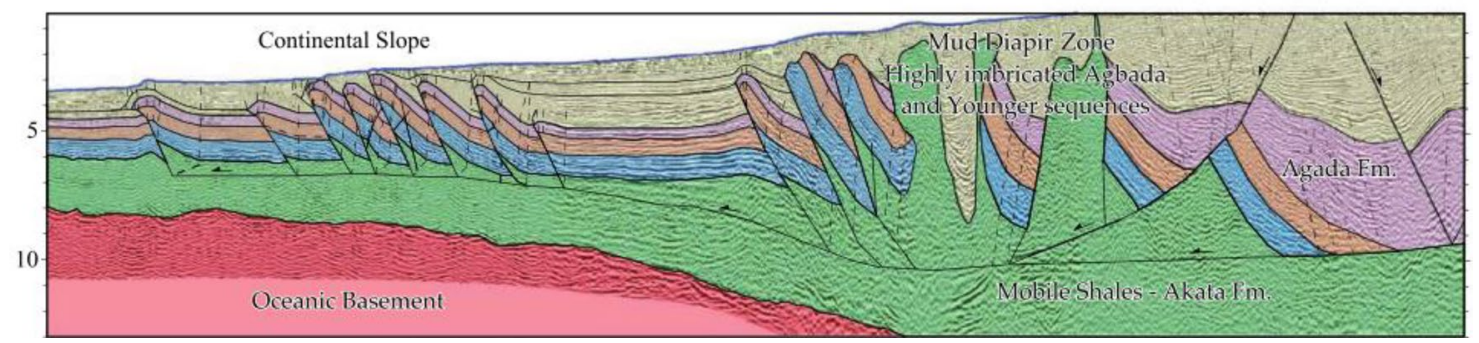

Fig. 3 Uninterpreted and interpreted regional seismic profile across the Niger Delta showing the structural zones (Corredor et al. 2005)

Table 1 Summary of the available data set for each of the studied wells

\begin{tabular}{lllll}
\hline Well log types & OSP-001 & OSP-002 & OSP-013 & OSP-010 \\
\hline Gamma ray & $\sqrt{ }$ & $\sqrt{ }$ & $\sqrt{ }$ & $\sqrt{ }$ \\
Sonic & $\sqrt{ }$ & $\sqrt{ }$ & $\times$ & $\sqrt{ }$ \\
Caliper (CAL) & $\sqrt{ }$ & $\sqrt{ }$ & $\times$ & $\times$ \\
Neutron porosity (NPHI) & $\sqrt{ }$ & $\sqrt{ }$ & $\sqrt{ }$ & $\sqrt{ }$ \\
Bulk Density (RHOB) & $\sqrt{ }$ & $\sqrt{ }$ & $\sqrt{ }$ & $\sqrt{ }$ \\
Deep resistivity (LL9D) & $\sqrt{ }$ & $\sqrt{ }$ & $\sqrt{ }$ & $\sqrt{ }$ \\
Shallow resistivity & $\times$ & $\times$ & $\sqrt{ }$ & $\times$ \\
$\quad$ LL9S) & & & & \\
Deviation data & $\sqrt{ }$ & $\sqrt{ }$ & $\sqrt{ }$ & $\sqrt{ }$ \\
Microfauna & $\sqrt{ }$ & $\sqrt{ }$ & $\times$ & $\times$ \\
Check shot data & $\sqrt{ }$ & $\times$ & $\times$ & $\times$ \\
\hline
\end{tabular}

$\sqrt{ }$ Available, $\times$ not available

sequence boundaries (SBs) from the biostratigraphic interpretation integrated with well log interpretation were used in correlating the sand units across the wells in order to establish the lateral continuity of the facies.

Faults were identified and mapped on the seismic lines as lateral discontinuities of seismic reflections. The chronostratigraphic surfaces interpreted from biostratigraphic and well log data were tied to the seismic volume using a synthetic seismogram. The chronostratigraphic surfaces were mapped as horizons across the entire seismic volume taking into consideration of available faults. This was done in order to establish the lateral continuity of the surfaces and systems tract across the entire field including areas without well control.

\section{Results and discussion \\ Reservoir identification}

On the basis of relatively low gamma ray values and corresponding high resistivity readings, six hydrocarbon reservoirs (Sand 1, 2, 3, 5, 6 and 8) were identified in OSP-002 (Fig. 7).

\section{Sequence stratigraphic interpretation}

\section{Biostratigraphic interpretation}

Three (3) and two (2) palynological subzones were delineated based on the biostratigraphic data provided for the OSP-001 and OSP-002, respectively. The two well sections fall within the F9600 foraminifera zone and this zones serves as the basis for the sequence stratigraphic interpretation of the field. 


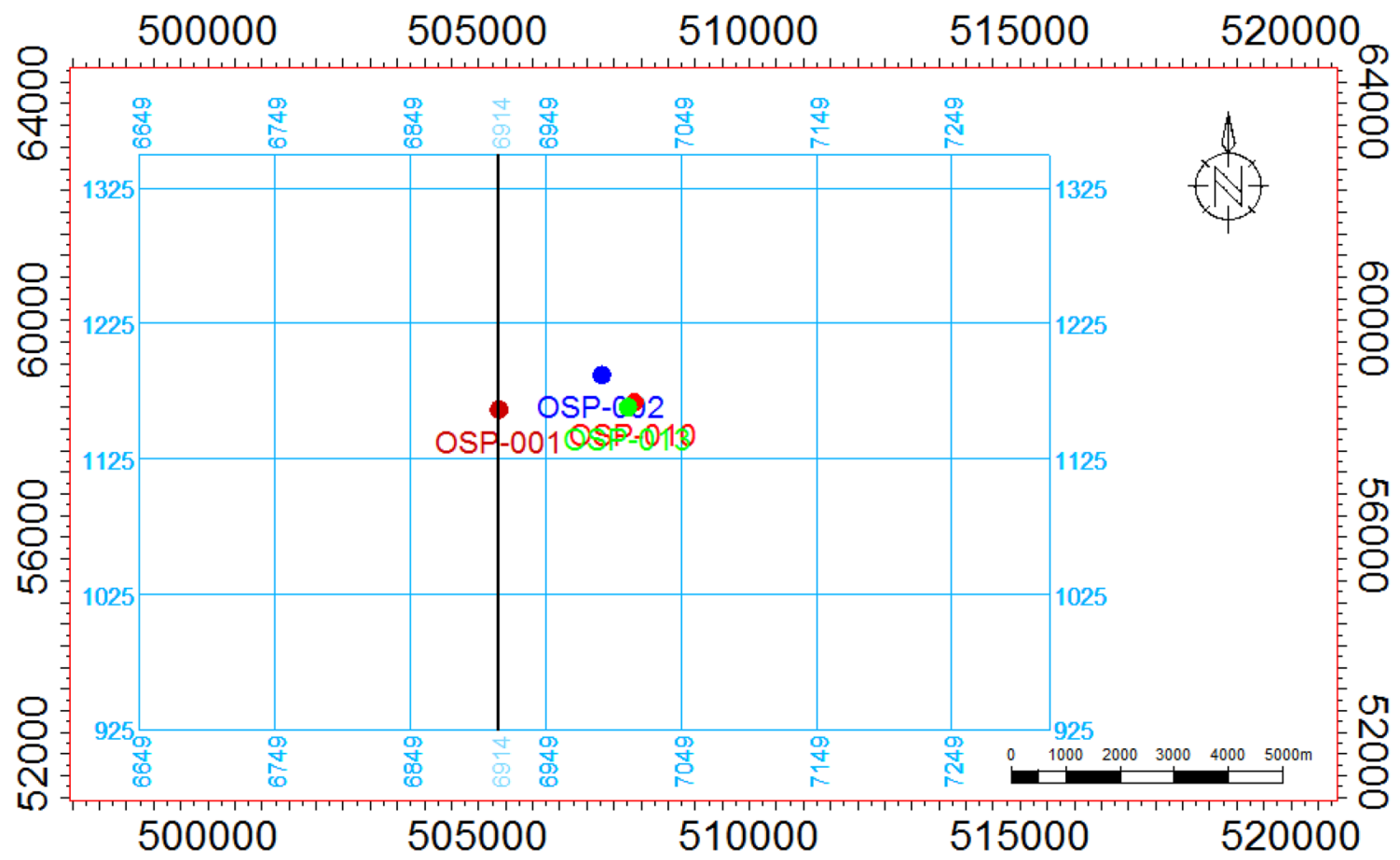

Fig. 4 Base map of the study area showing well locations. Note: the seismic inline that was discussed in this study is in thick black (inline 6914)

In OSP-001, the deepest palynological subzone is the P780, followed by P820 zone and the shallowest is the P830 subzone (Table 2). Based on microfaunal abundance and diversity maxima, three condensed sections were identified in the well. The deepest condensed section was observed at about $10,600-10,850 \mathrm{ft}$, followed by that observed within interval $9300-9700 \mathrm{ft}$. The shallowest condensed section was recorded within interval $8200-8400 \mathrm{ft}$. The ages of the condensed section were estimated based on their occurrence within the P780, P820 and P830 palynological subzones as well as the F9600 foraminifera zones. The three (3) condensed sections identified within these zones are believed to be associated with the 7.4, 9.5, 10.4 Ma maximum flooding surfaces (Table 2). A Middle-Late Miocene age was assigned to the studied interval based on the identified foraminifera zone and palynological subzones for OSP-001.

The P780 and P820 palynological subzones and the F9600 foraminifera zone were recognized in the OSP-002. Two condensed sections, recognized from the microfauna abundance and diversity maxima were identified at intervals 10,200-10,450 ft and 9200-9000 ft, were associated with the $10.4 \mathrm{Ma}$ and $9.5 \mathrm{Ma}$ maximum flooding surfaces, respectively. The OSP-002 well section was also dated Middle-Late Miocene on the basis of the recognized palynological subzones and foraminifera zone.

It was on the basis of the biostratigraphic results from these two wells (OSP-001 and OSP-002) that the ages of the condensed sections were extrapolated across the field (Table 3).

\section{Key stratigraphic surfaces}

The identification of key stratigraphic surfaces was first carried out on the wells with biostratigraphic information (OSP-001 and OSP-002) and then interpolated to the other wells in the study area.

The maximum flooding surfaces (MFS) identified from the biostratigraphic data coincide with surfaces between a retrograding unit and an overlying prograding unit on gamma ray log. The sequence boundaries in this study coincide with clean sand abruptly overlying a shale.

\section{Maximum flooding surfaces (MFS)}

Three maximum flooding surfaces (7.4, 9.5 and 10.4 Ma) were identified in OSP-001 well and two maximum flooding surfaces (9.5 and 10.4 Ma) were identified in OSP-002 well. These maximum flooding surfaces correspond with gamma peaks within stacked packages at different depths on the logs. The ages of the MFSs were determined after a careful correlation of the identified condensed sections with the Niger Delta chronostratigraphic chart of Haq et al. (1988) (Fig. 5). 


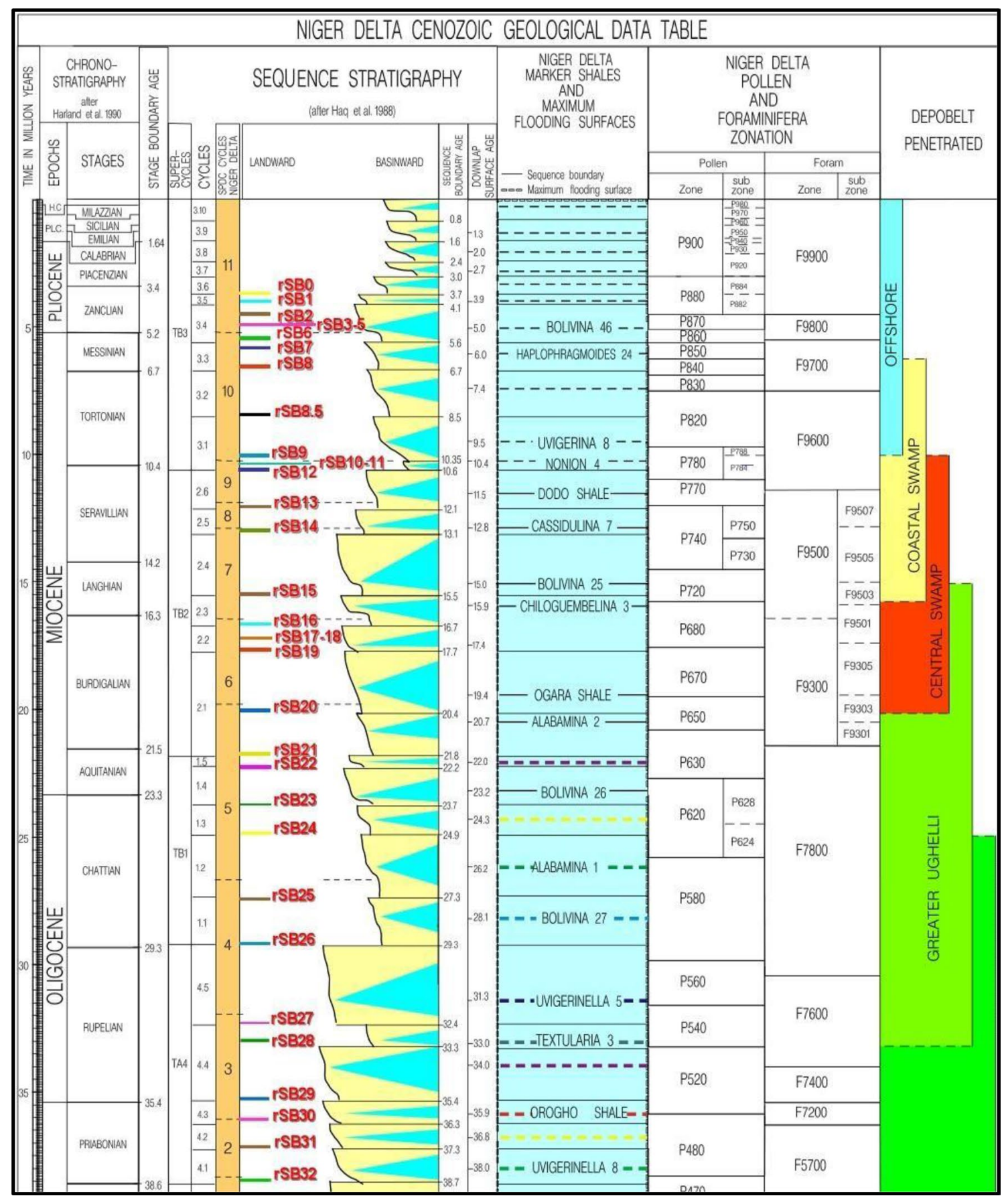

Fig. 5 Niger Delta Cenozoic chronostratigraphic chart (after Haq et al. 1988)

\subsection{MFS}

This occurs within the P780 palynological sub zone and F9600 foraminifera zone. The 10.4 MFS was identified at a depth of about 10,812 ft in OSP-001 (Fig. 8) and at a depth of 10,412 ft in OSP-002 (Fig. 9). This surface was correlated across other wells in the study area.

\subsection{MFS}

This surface occurs within the P820 palynological subzone and F9600 foraminifera zone. The 9.5 MFS was identified at a depth of about $9437 \mathrm{ft}$ in OSP-001 (Fig. 8) and at a depth of $9196 \mathrm{ft}$. in OSP-002 (Fig. 9). 


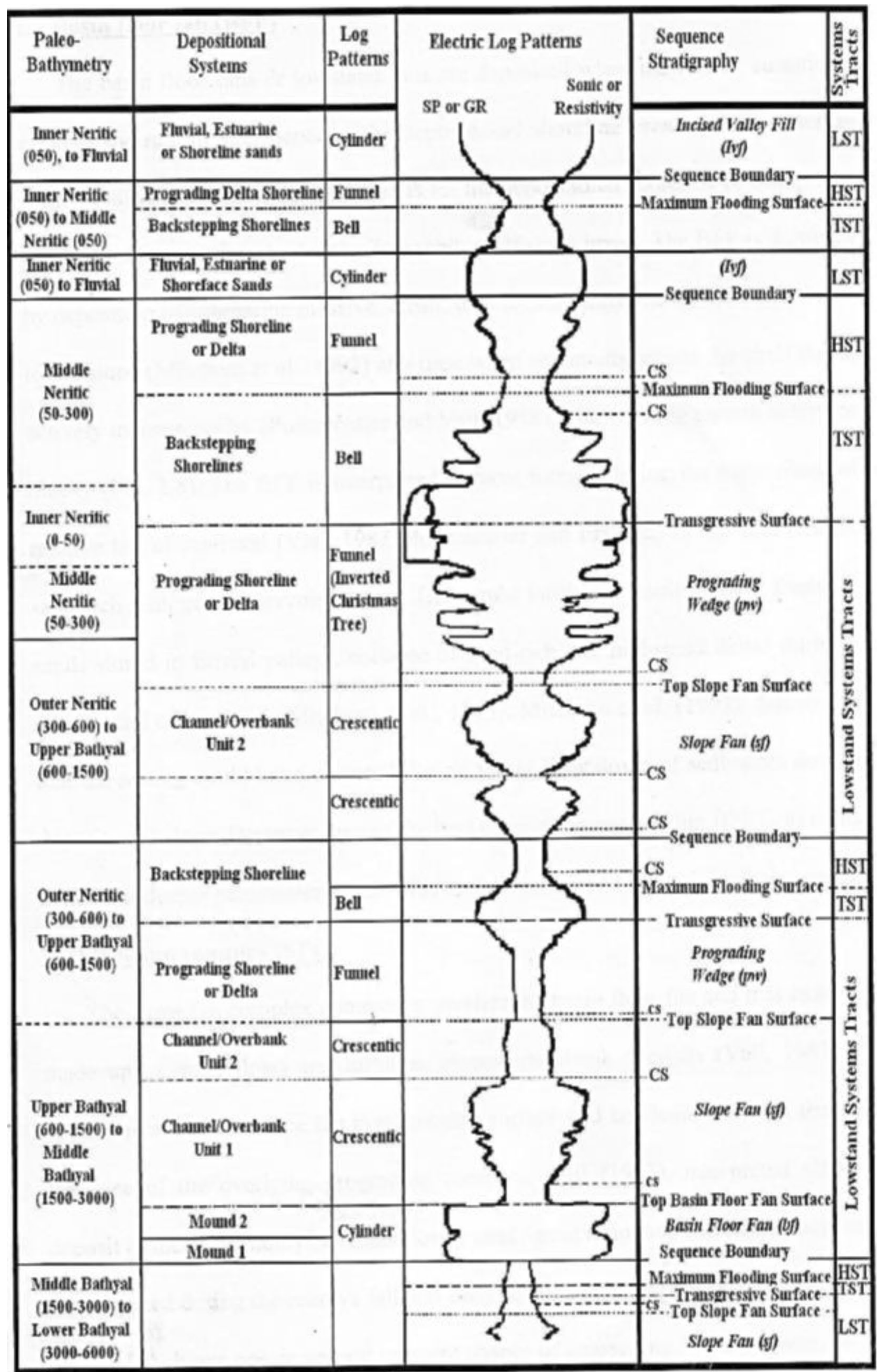

Fig. 6 Typical Log patterns associated with Gulf of Mexico depositional sequences and systems tract (after Vail 1987) 


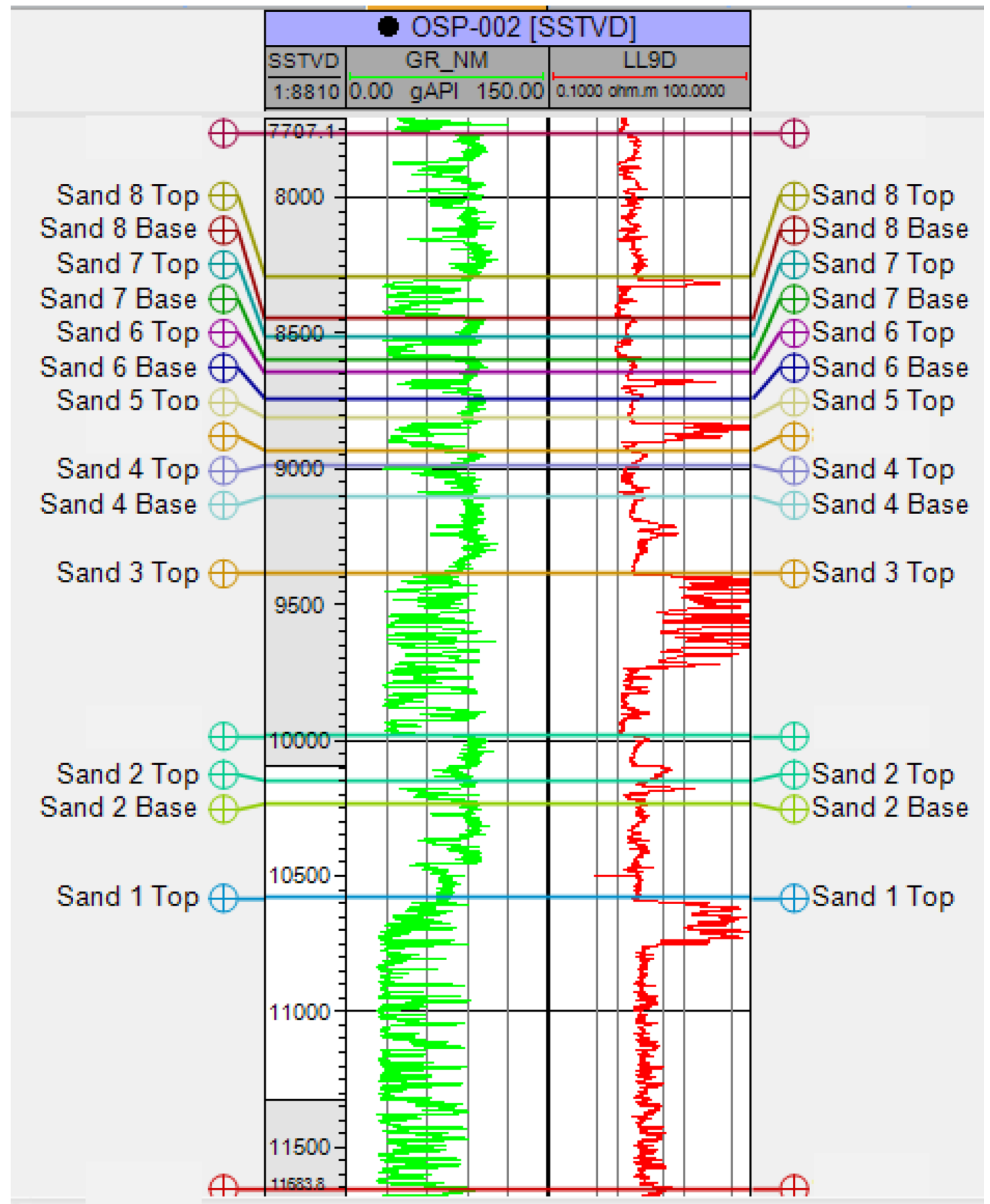

Fig. 7 Identified hydrocarbon bearing reservoirs

\subsection{MFS}

The maximum flooding surface occurs within the P830 palynological subzone and F9600 foraminifera zone. The 7.4 MFS was identified at a depth of about $8163 \mathrm{ft}$ in OSP001 and this surface was interpolated at depth $8202 \mathrm{ft}$ in OSP-002 (Fig. 9).

\section{Sequence boundaries (SB)}

Four sequence boundaries were identified in the two wells (OSP-001 and OSP-002), based on sharp GR transition from shale to sand. These were dated based on the biozones in which they occur. 
Table 2 Biostratigraphic summary of OSP-001

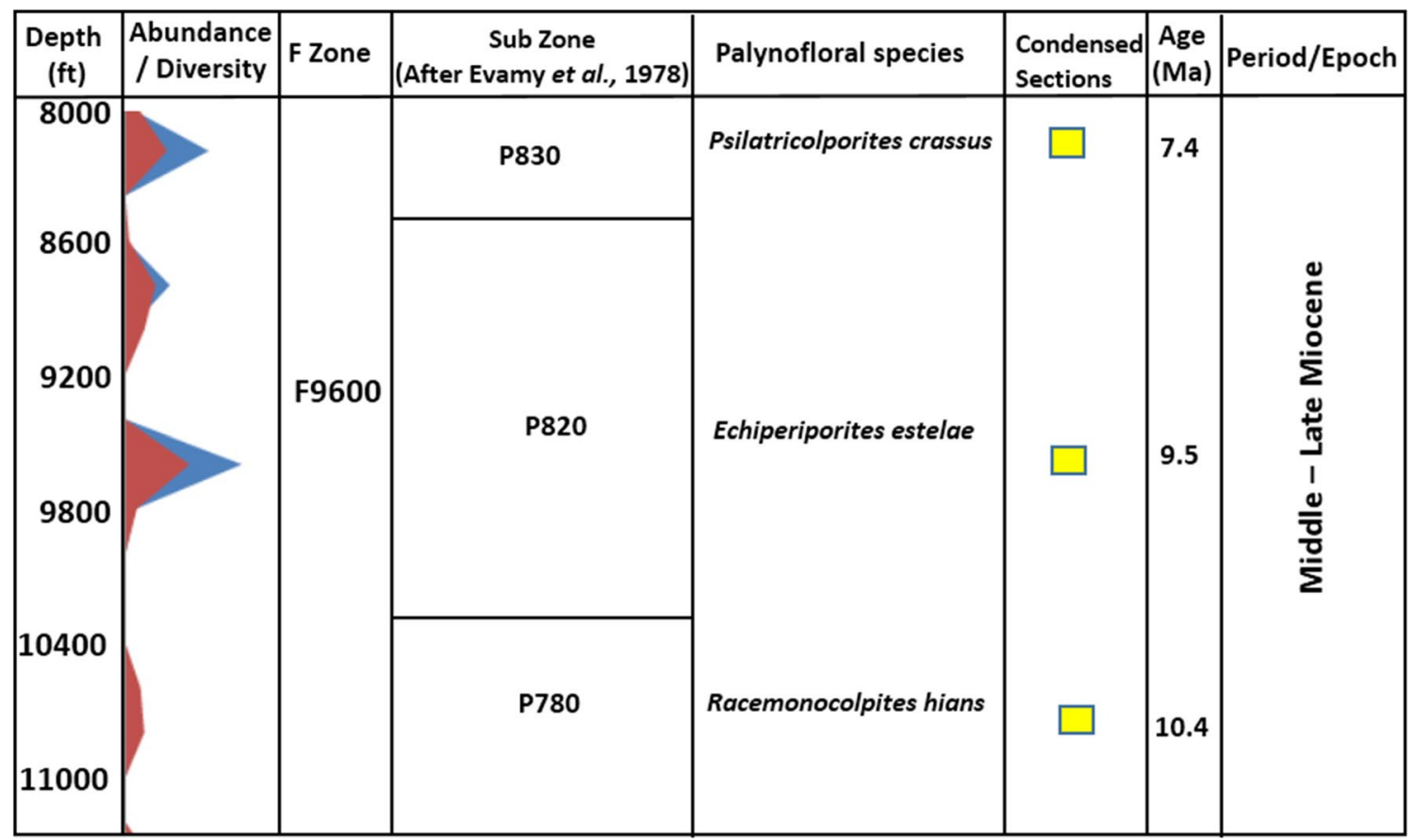

Table 3 Biostratigraphic summary of OSP-002

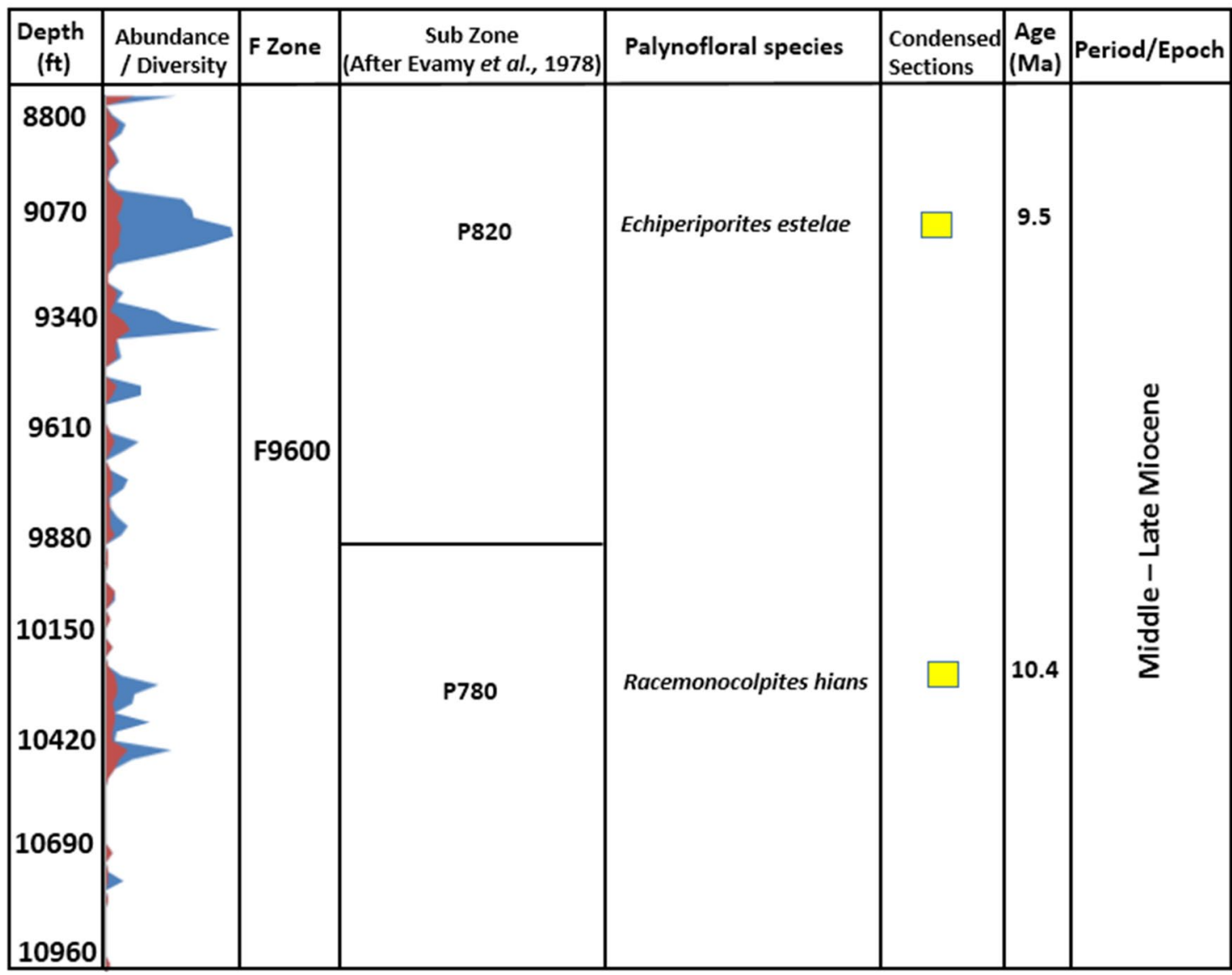




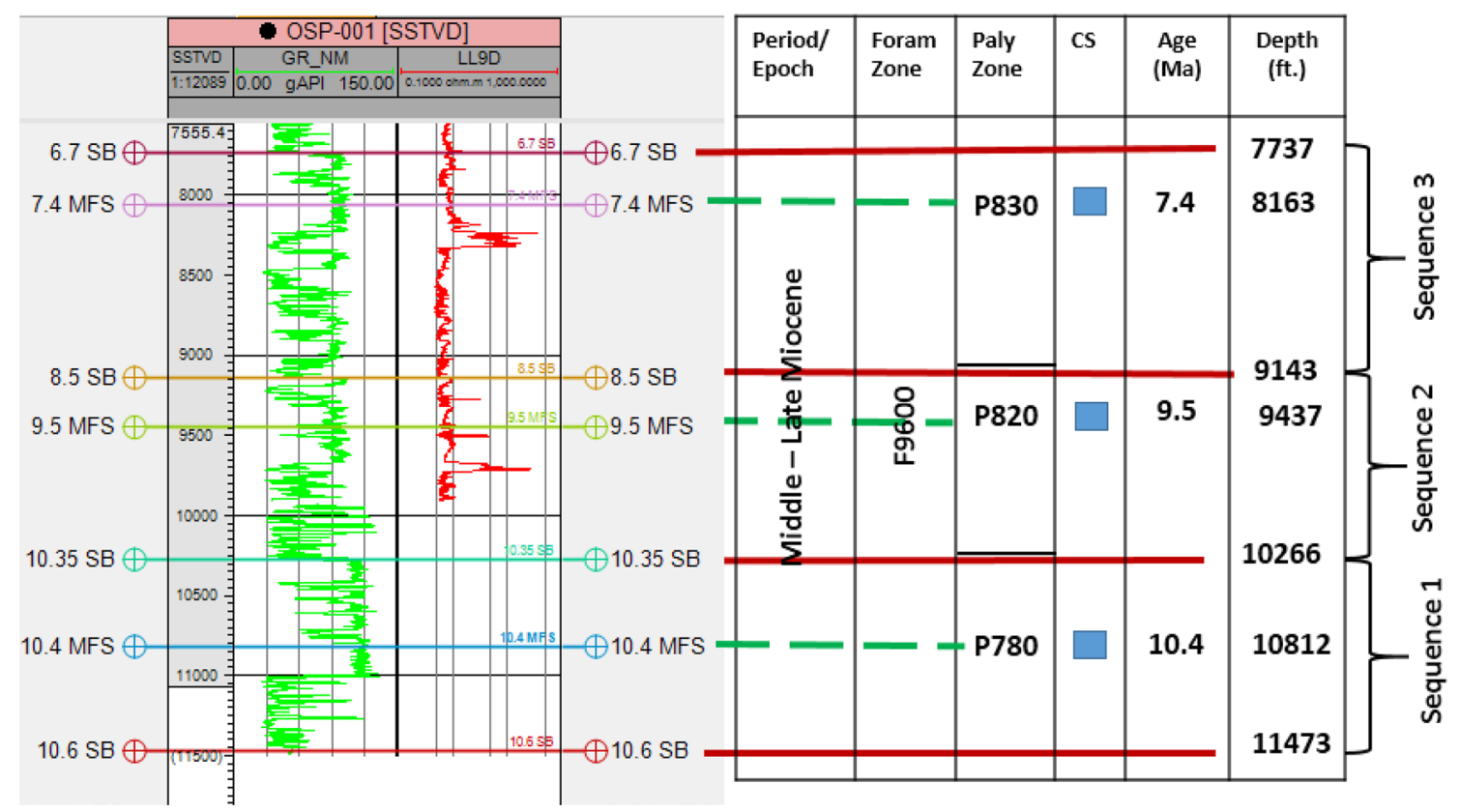

Fig. 8 Key stratigraphic surface identified in OSP-001

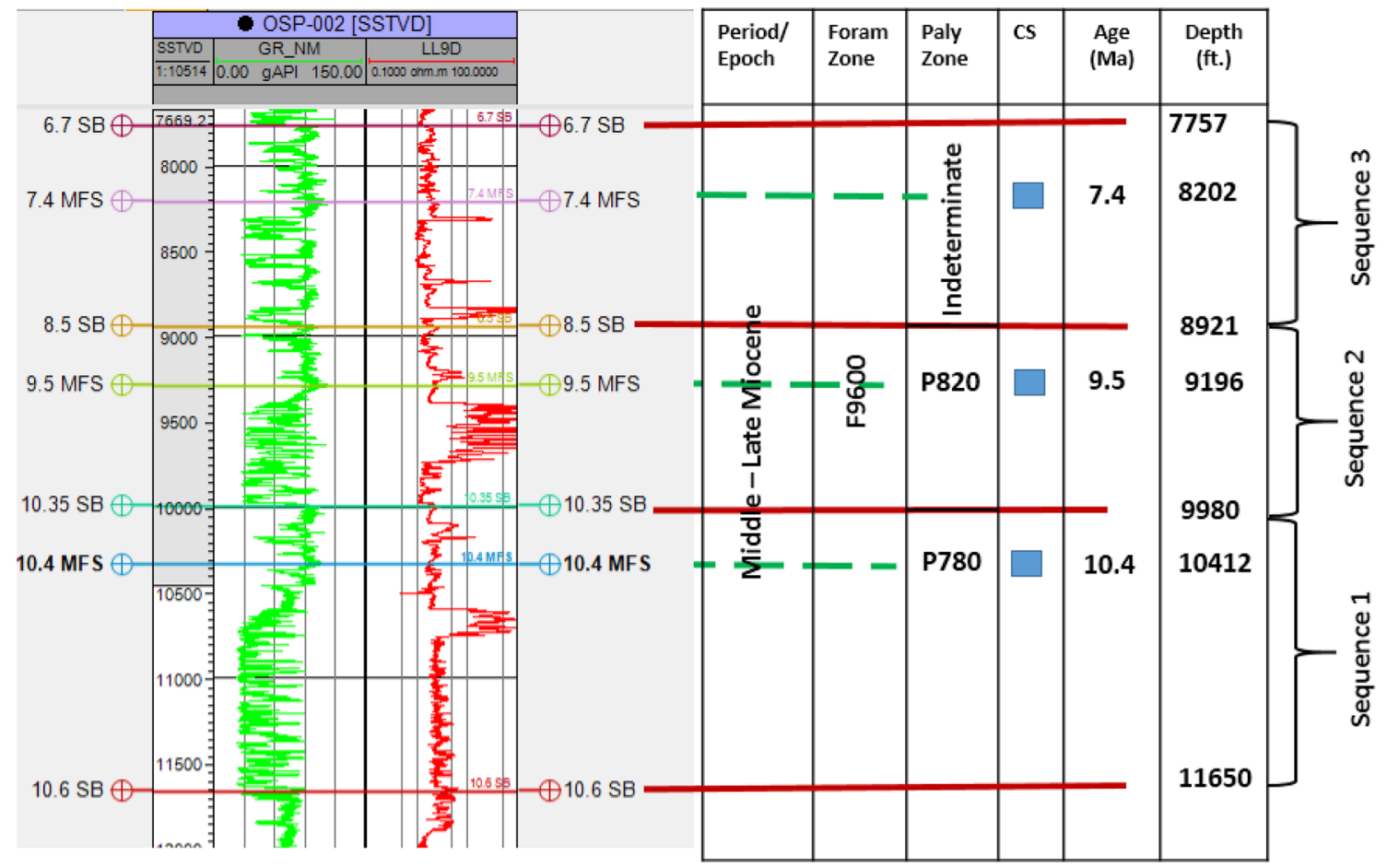

Fig. 9 Key stratigraphic surface identified in OSP 002

\section{$10.6 \mathrm{SB}$}

This is the oldest SB in the study area. The surface falls within the last down appearance of P780 palynological subzone and F9600 foraminiferal zone. The age of this surface was determined after correlating of the identified palynological zone boundary with the Niger Delta chronostratigraphic chart of Haq et al. (1988). The surface was identified at a depth of 11,650 ft in OSP-002 (Fig. 9). 


\subsection{SB}

It occurs within the F9600 foraminifera zone and last down occurrence P820 palynological subzone. This surface was identified at a depth of 10,266 ft in OSP-001 and $9980 \mathrm{ft}$ in OSP-002 (Figs. 8, 9).

\subsection{SB}

The surface occurs within the P830 palynological subzone and the F9600 foraminiferal zone. This surface was identified at a depth of $9143 \mathrm{ft}$ and $8921 \mathrm{ft}$ in OSP-001 and OSP-002, respectively.

\subsection{SB}

This is the youngest sequence boundary within the studied wells. The surface was interpolated at depth $7737 \mathrm{ft}$ in OSP-001 and $7757 \mathrm{ft}$ in OSP-002 (Figs. 8, 9). The age of this surface could not be ascertained due to lack of biostratigrahic information for the depth range where the sequence boundary (SB) was identified. The assigned age to the sequence boundary was therefore based on its stratigraphic position above the positively recognized 7.4 Ma MFS.

\section{Depositional sequences and systems tract}

Three (3) depositional sequences (sequence 1, sequence 2 and sequence 3) made up of the lowstand systems tract (LST), transgressive systems tract (TST) and the highstand systems tract (HST) were identified across the studied wells.

\section{Sequence 1}

This sequence is the oldest of the depositional sequences in the study area. It is bounded below by the $10.6 \mathrm{Ma} \mathrm{SB}$ and above by the $10.35 \mathrm{Ma}$ SB. It is approximately $1670 \mathrm{ft}$ thick in OSP-002 (Fig. 9). The sequence was identified in OSP-001, OSP-002 and OSP-010 as these well penetrated deeper in to the subsurface than the OSP-013 well. The Lowstand Systems Tract (LST 1) of Sequence 1 formed thick sand deposits whose blocky GR log motif were interpreted as fluvial channel deposits. LST 1 is bounded below by the 10.4 Ma SB and above by the trangressive surface (TS 1). The Transgressive Systems Tract (TST 1) of Sequence 1, bounded below by TS 1 and the $10.4 \mathrm{Ma}$ MFS above is composed of relatively thin-bedded shales which were deposited during a relatively short period of base-level rise. The Highstand Systems Tract (HST 1) of this sequence is composed of prograding shales and sands bounded below by the10.4 Ma MFS and above by the upper bounding surface (10.35 Ma SB) of the sequence (Figs. 8, 9).

\section{Sequence 2}

The sequence is bounded below and above by the $10.35 \mathrm{Ma}$ and 8.5 Ma SBs, respectively. This sequence is about 1123 $\mathrm{ft}$ and $1059 \mathrm{ft}$ thick in OSP-001 and OSP-002, respectively (Figs. 8, 9). The sequence was identified in the four studied well in the study area. The Lowstand Systems Tract (LST 2) was identified based on its stratigraphic position directly above the $10.35 \mathrm{Ma} \mathrm{SB}$. The LST is characterized by a blocky profile on the gamma ray log and the top of this systems tract was marked by the trangressive surface (TS2). The Transgressive Systems Tract (TST 2) of Sequence 2, bounded below by TS 2 and the 9.5 Ma MFS above is composed of relatively thin-bedded shales which were deposited during a relatively short period of base-level rise. The Highstand Systems Tract (HST 2) of the sequence 2 is composed of coarsening upward GR log motif bounded below by the $9.5 \mathrm{Ma}$ MFS and above by the upper bounding surface (8.5 Ma SB) of the sequence (Figs. 8, 9).

\section{Sequence 3}

This sequence is bounded below by the $8.5 \mathrm{Ma} \mathrm{SB}$ and capped above by the $6.7 \mathrm{Ma}$ SB. The sequence is about 1406 $\mathrm{ft}$ and $1164 \mathrm{ft}$ thick in OSP-001 and OSP-002, respectively. The Lowstand Systems Tract (LST 3) was identified based on its stratigraphic position directly above the $8.5 \mathrm{Ma}$ SB. The top of LST 3 was marked by the transgressive surface (TS3). The Lowstand Systems Tract (LST 3) of Sequence 3 formed thick sand and shale intercalation deposits whose funnel GR log motif were interpreted as fluvial channel mouth bar deposits. The Transgressive Systems Tract (TST 3) of Sequence 3, bounded below by TS 3 and the $7.4 \mathrm{Ma}$ MFS above is composed of relatively thin-bedded shales which were deposited during a relatively short period of base-level rise. The Highstand Systems Tract (HST 3) was identified based on its stratigraphic position directly above the 7.4 Ma maximum flooding surface. The HST 3 was characterized by a coarsening upward profile on the gamma ray $\log$ and bounded above by the $6.7 \mathrm{Ma}$ sequence boundary (Figs. 8, 9).

\section{Well correlation and hydrocarbon potential of the depositional systems}

The recognized chronostratigraphic surfaces (maximum flooding surfaces (MFSs) and sequence boundaries (SBs) from the biostratigraphic interpretation integrated with

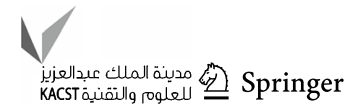




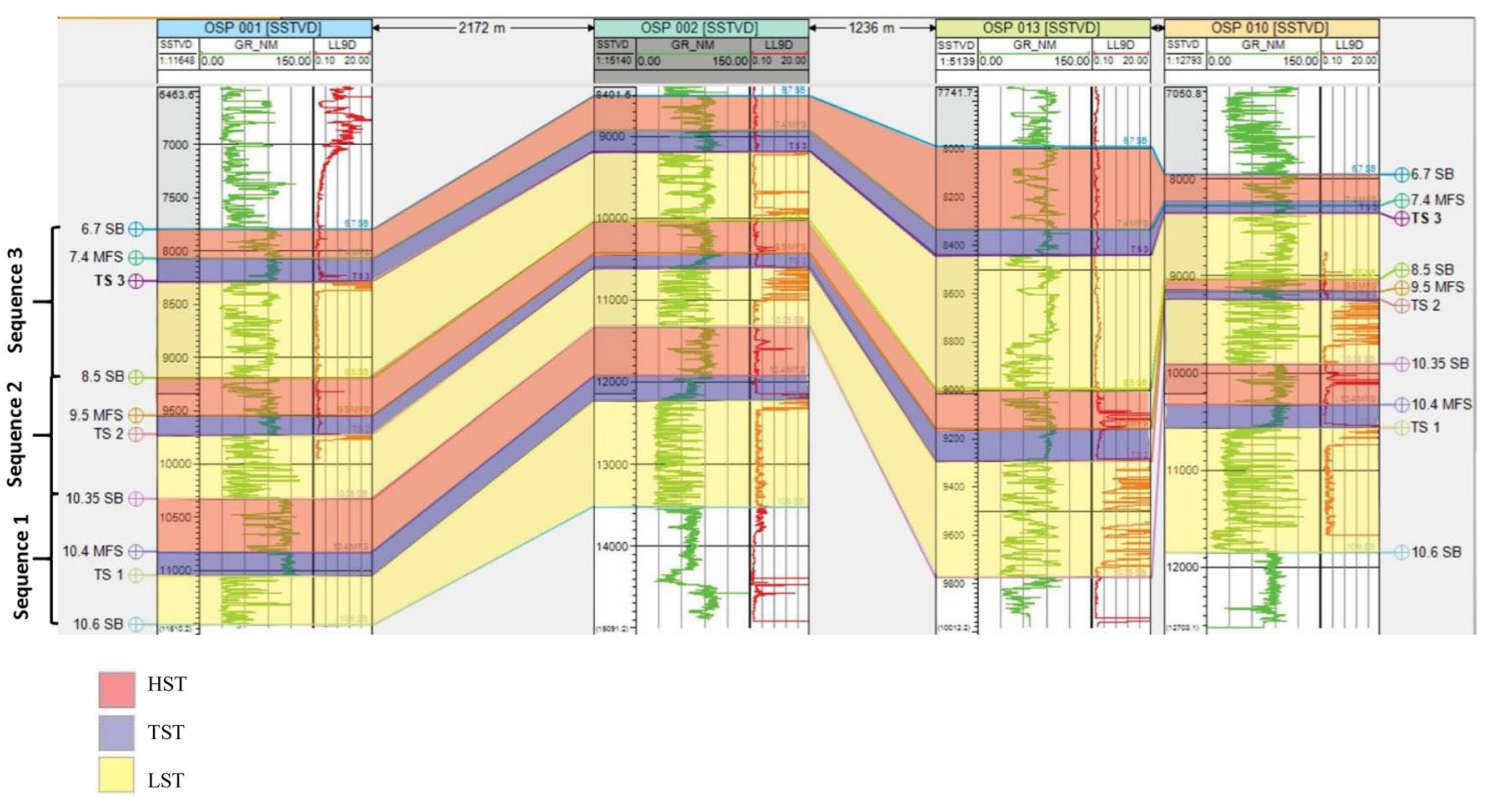

Fig. 10 Stratigraphic surfaces and systems tracts across OSP field

well log interpretation from OSP-001 and OSP-002 wells were interpolated to the other two wells (OSP-010 and OSP-013) in the study area (Fig. 10). Sequence 1 was observed not to be laterally continuous across all the studied wells as OSP-013 well did not penetrate this sequence. OSP-013 was observed to be the shallowest of the studied wells (Fig. 10). Both sequences 2 and 3 are laterally continuous in all the studied wells (Fig. 10). The key chronostratigraphic surfaces and systems tract framework of the studied wells are presented in Fig. 10.

The recognized chronostratigraphic surfaces were used in correlating the sand units across the wells in order to establish the lateral continuity of the facies (Fig. 11). Eight sand units were identified and correlated across the four wells in the study area.

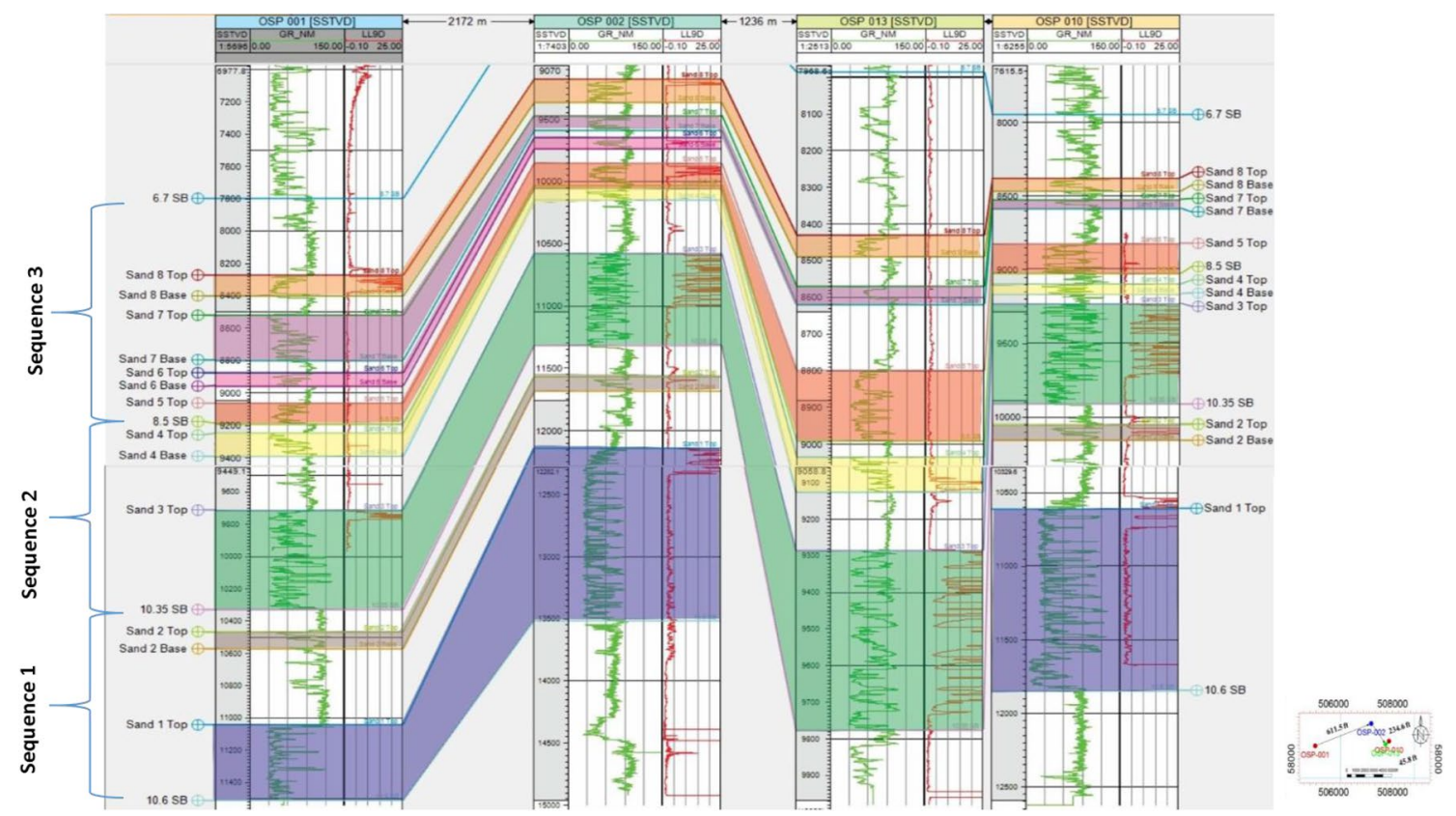

Fig. 11 Cross section of the studied well showing identified hydrocarbon bearing reservoirs using the sequence stratigraphic method 


\section{Sand 1}

This sand was identified and correlated in OSP-002 and OSP-010 at intervals 10,606-11,654 ft and 10,527-11,826 $\mathrm{ft}$, respectively. It was observed to contain hydrocarbon based on the high resistivity log signature at this interval. This sand overlies the 10.6 Ma SB and it is characterized by a blocky profile on the gamma ray log. This sand belongs to the lowstand systems tract 1 (LST 1) of sequence1. The exact depth of this sand in wells OSP-001 and OSP-013 could not be established due to the absence of $\log$ data (Fig. 11).

\section{Sand 2}

This sand was observed to be a thin sand unit that was identified and correlated in OSP-001, OSP-002 and OSP010 at intervals $10,279-11,005 \mathrm{ft}, 10,082-10,245 \mathrm{ft}$, and 10,053-10,318 ft, respectively. This sand unit is hydrocarbon-bearing based on high resistivity signature of the unit. This sand unit was bounded above and below by the 10.35 Ma SB and 10.4 Ma MFS, respectively. It is characterized by a funnel-shaped profile on the gamma ray log and this sand belongs to the highstand systems tract 1 (HST 1) of sequence 1 (Fig. 11).

\section{Sand 3}

This sand was identified and correlated across the four studied wells. It was found to be with an average thickness of about $645 \mathrm{ft}$. This sand unit overlies the $10.35 \mathrm{Ma} \mathrm{SB}$ and was observed to contain hydrocarbon in all the wells based on the high resistivity signatures of the unit. This sand unit is characterized by a blocky profile on the gamma ray log and it belongs to the lowstand systems tract 2 (LST 2) of sequence 2 (Fig. 11).

\section{Sand 4}

The sand was identified to contain hydrocarbon only in OSP013 based on the high resistivity log signature at interval 9023-9138 ft. However, the sand in wells OSP-001, OSP002 and OSP-010 were interpreted as water-bearing sands as inferred from their low resistivity values at intervals 9190-9309 ft, 8986-9094 ft and 8956-9038 ft, respectively. This sand unit was bounded above and below by the $8.5 \mathrm{Ma}$ SB and 9.5 Ma MFS, respectively. This sand unit is characterized by a funnel shaped profile on the gamma ray log and it belongs to the highstand system tract 2 (HST 2) of sequence 2 (Fig. 11).

\section{Sand 5}

This sand unit was identified as a thin sand unit with an average thickness of about $110 \mathrm{ft}$. This sand unit was observed to be hydrocarbon-bearing in well OSP-002 at interval 8814-8931 ft due to the high resistivity log values. However, this sand in wells OSP-001, OSP-013 and OSP-010 at intervals 9034-9135 ft, 8799-8991 ft and 8838-8920 ft were found to be water-bearing due to their low resistivity values, respectively. This sand unit overlies the 8.5 Ma SB (Fig. 11).

\section{Sand 6}

This sand unit was identified and correlated at intervals 8845-8910 ft and 8665-8710 ft in OSP-001 and OSP-002, respectively. This sand is thin and it was observed to thinout in OSP-013 and OSP-010. This sand was interpreted to contain hydrocarbon only in well OSP-002 due to its high resistivity log signature in the well (Fig. 11).

\section{Sand 7}

This sand unit was identified and correlated in OSP-001, OSP-002, OSP-013 and OSP-010. This sand unit was observed to be water-bearing as inferred from their low resistivity values across the wells (Fig. 11).

\section{Sand 8}

The sand was identified and correlated at intervals 8229-8358 ft, 8286-8448 ft, 8071-8154 ft and 8387-8442 ft in OSP-001, OSP-002, OSP-013 and OSP-010, respectively. This sand unit was observed to be hydrocarbon-bearing in OSP-001 and OSP-002 (Fig. 11).

The identified sand units with hydrocarbon falls within the highstand and lowstand systems tracts in the study area. In sequence 1, the highstand systems tract (HST 1) and the lowstand systems tract (LST 1) host the hydrocarbon reservoirs, the reservoirs has a thickness ranging from 110-156 $\mathrm{ft}$ and 532-1299 ft, respectively. The hydrocarbon unit in sequence 2 belongs to the LST 2 reservoir, with a thickness ranging from 610 to $682 \mathrm{ft}$. In sequence 3 the LST 3 unit host the hydrocarbon reservoir with a thickness ranging from 523 to $945 \mathrm{ft}$ (Fig. 12).

\section{Seismic interpretation}

To understand the structural framework of the study field, faults were mapped throughout the seismic volume. These faults were represented on the seismic sections as discontinuous reflections along a preferred orientation of reflectors (Fig. 13). A total of twenty (20) faults coded F1 to F20 were identified and mapped throughout the seismic volume.

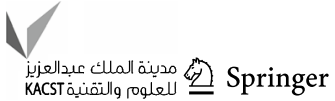


Fig. 12 Thicknesses of the systems tracts that contains hydrocarbon

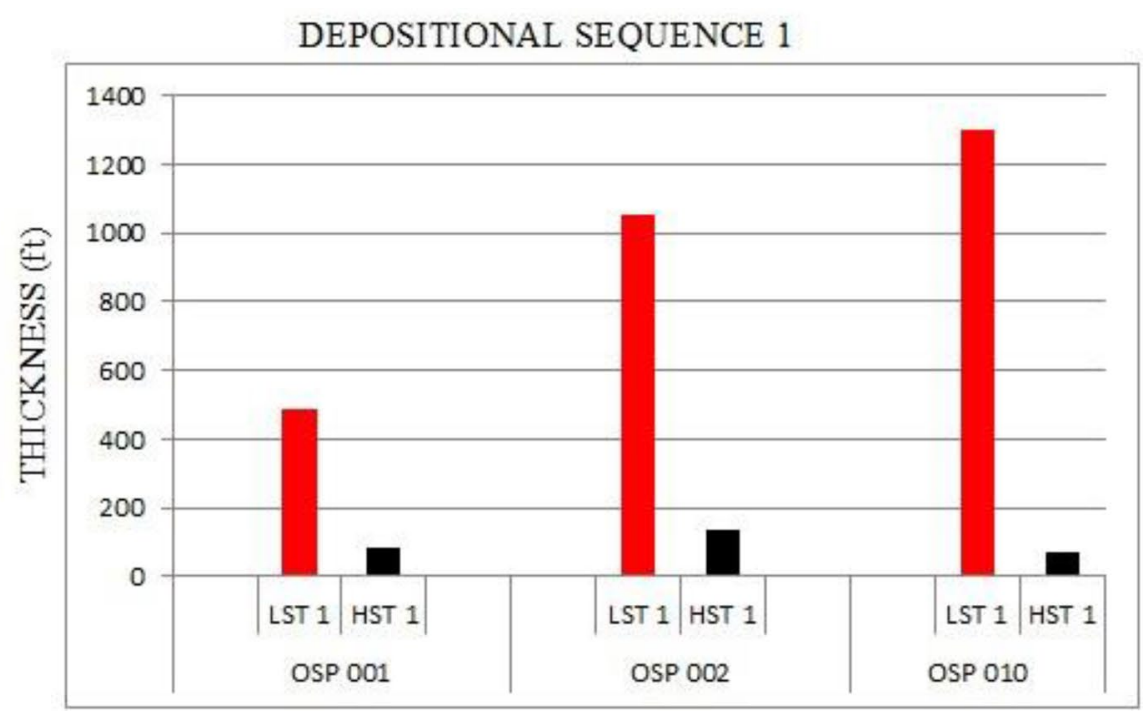

DEPOSITIONAL SEOUENCE 2

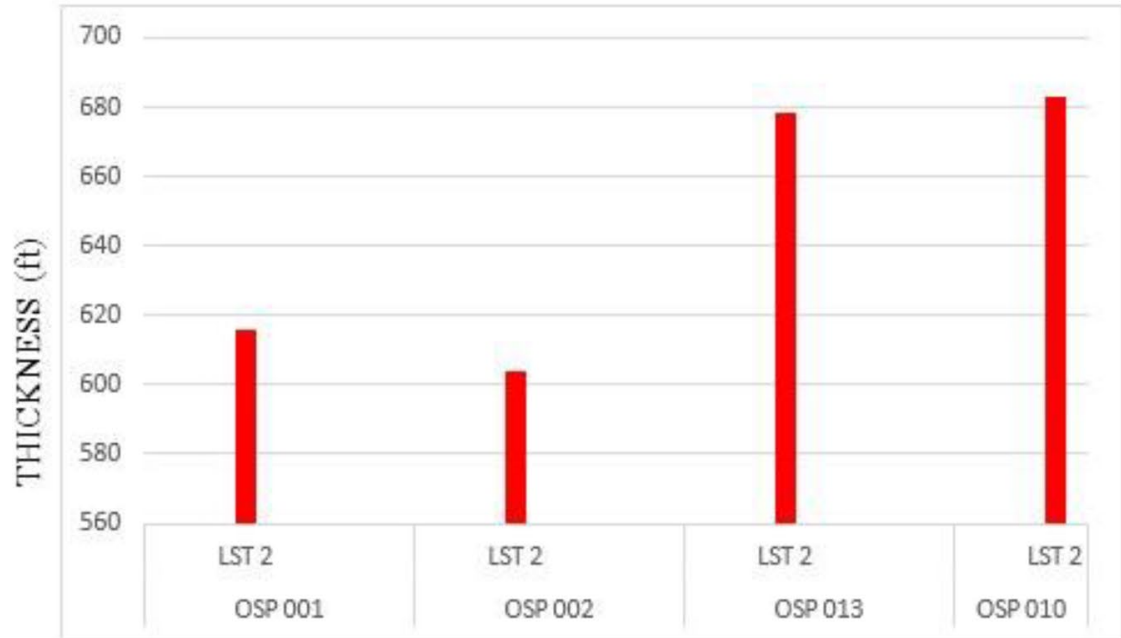

DEPOSITIONAL SEQUENCE 3

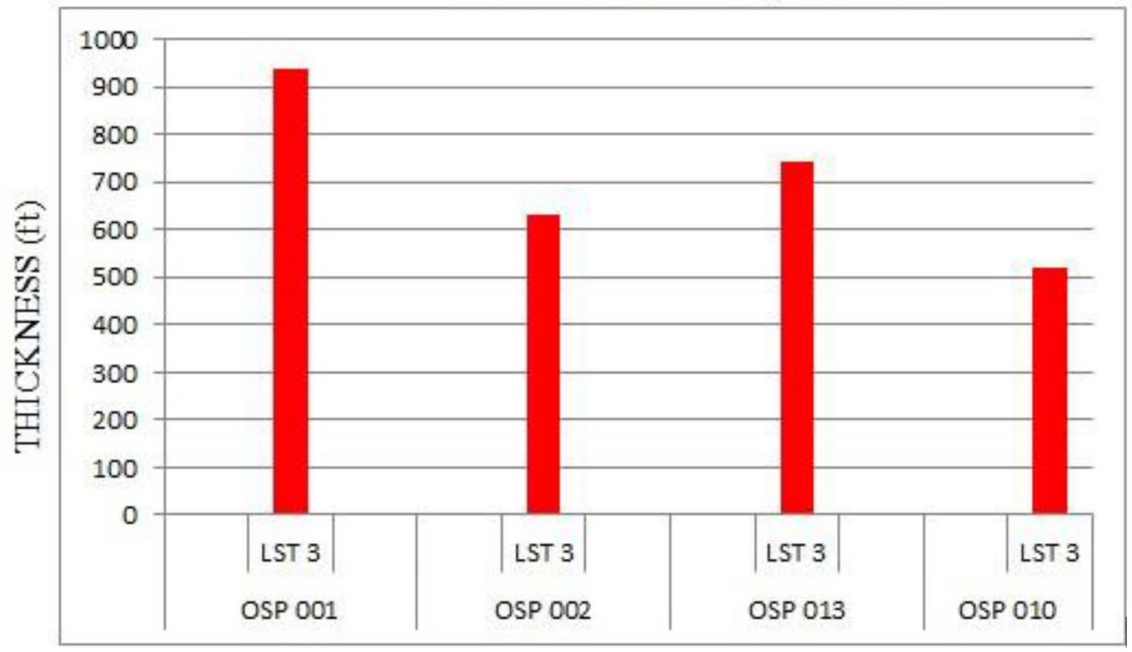




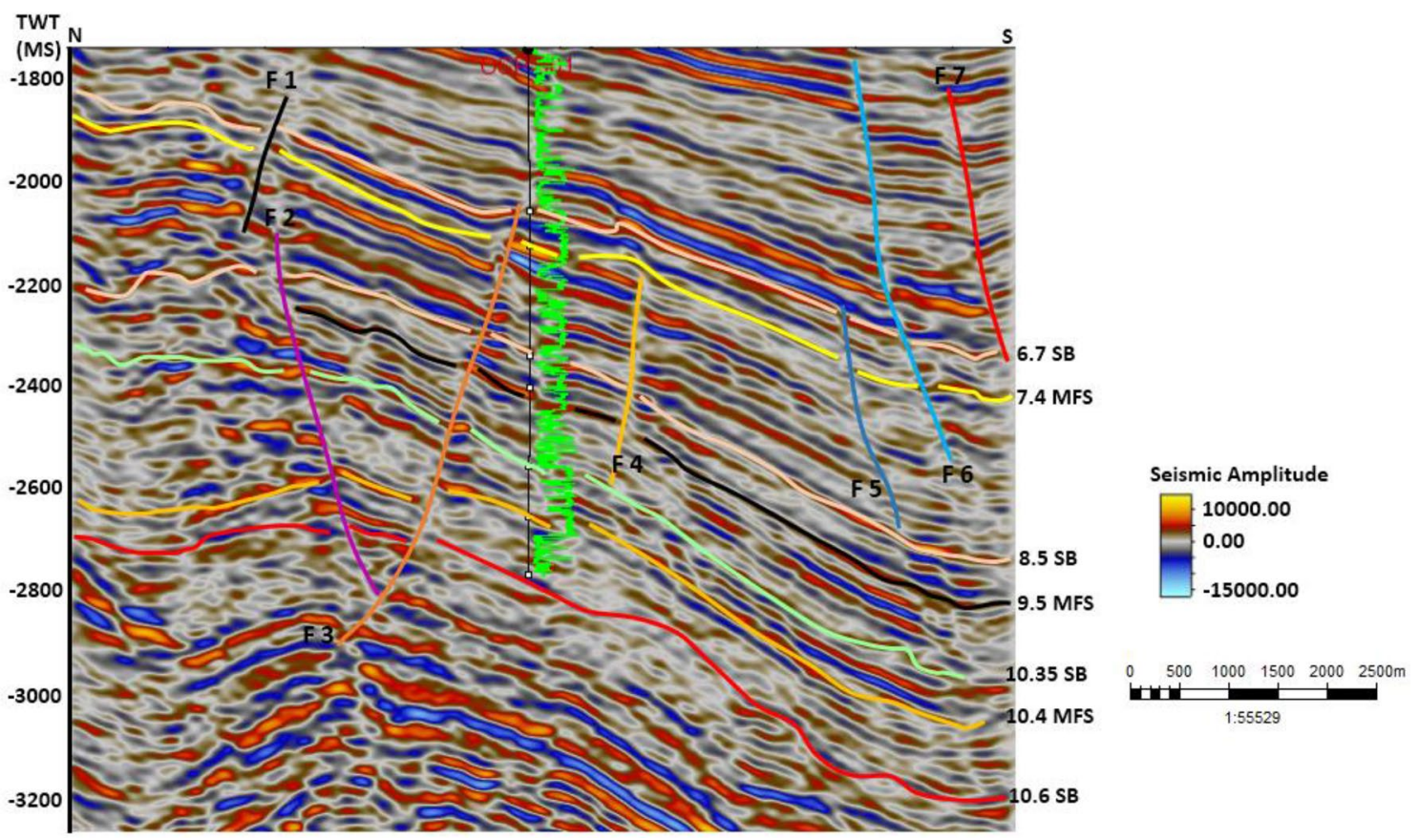

Fig. 13 Seismic section showing mapped faults and chronostratigraphic horizons (see Fig. 4 for location)

The faults are normal faults. Seven horizons of interest were mapped across the seismic volume, this horizons correspond to the identified chronostratigraphic surfaces from well logs. This was done to establish the sequence stratigraphic framework of the study area away from areas without well control (Fig. 13).

\section{Summaries and conclusions}

Biostratigraphic interpretation reveled that OSP-001 and OSP-002 wells falls within the F9600 foraminiferal zone as well as the P800 (P820, P830 subzones) and P700 (P780 subzone) palynological zones. This indicates that both wells (OSP-001 and OSP-002) ranged between the Middle to Late Miocene. Three main depositional sequences (sequence 1 , sequence 2 and sequence 3 ) comprising of the lowstand systems tract (LST), transgressive systems tract (TST) and Highstand systems tract (HST) were recognized in the study area. The sequences were bounded by four (4) sequence boundaries dated 10.6 Ma, 10.35 Ma, 8.5 Ma and 6.7 Ma based on the available biostratigraphic data. Three maximum flooding surfaces; 10.4 Ma, 9.5 Ma and 7.4 Ma were also identified.

Eight (8) sand units labeled sand 1 through to 8 were encountered within the study area. The hydrocarbon-bearing sand units within the study area are of the lowstand and highstand systems tracts. The highstand systems tract (HST 1) and the lowstand systems tract (LST 1) reservoirs of sequence 1 have thicknesses ranging from $110-156 \mathrm{ft}$ and 532-1299 ft, respectively. In sequence 2, the LST 2 reservoir thickness range from 610 to $682 \mathrm{ft}$. The LST 3 reservoir has a thickness ranging from 523 to $945 \mathrm{ft}$. A total of twenty faults (F1-F20) were identified and mapped on the seismic volume. Horizons corresponding to the chronostratigraphic surface were mapped. The mapped chronostratigraphic surfaces were used to establish the chronostratigraphic framework of the study area. The key chronostratigraphic surfaces identified in this study area are laterally continuous across the entire field (OSP field). Sequence 1 is the oldest sequence in the study area and it is not laterally continuous in the studied wells as OSP013 well did not penetrate deeper into the subsurface. The seismic interpretation aided the identification of chronostratigraphic surface across the entire field away areas without well control.

The sequence stratigraphic analysis mode of correlation employed in this study identified some thin hydrocarbon bearing reservoirs which are not laterally continuous across the wells. These discontinuities are predicted by the authors to be as a result of the stratigraphy and structural complexity of the field. Some reservoir units were identified to be hydrocarbon-bearing in some wells and wet in other wells. The compartmentalization of these reservoirs were attributed to the stratigraphy and structural settings of the field.

Acknowledgements The authors would like to thank Department of Petroleum Resources (DPR) and the Department of Geology, Obafemi

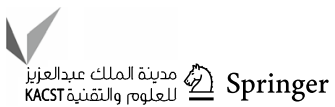


Awolowo University, Ile-Ife for making available for use, the data set and enabling environment, respectively.

Open Access This article is licensed under a Creative Commons Attribution 4.0 International License, which permits use, sharing, adaptation, distribution and reproduction in any medium or format, as long as you give appropriate credit to the original author(s) and the source, provide a link to the Creative Commons licence, and indicate if changes were made. The images or other third party material in this article are included in the article's Creative Commons licence, unless indicated otherwise in a credit line to the material. If material is not included in the article's Creative Commons licence and your intended use is not permitted by statutory regulation or exceeds the permitted use, you will need to obtain permission directly from the copyright holder. To view a copy of this licence, visit http://creativecommons.org/licenses/by/4.0/.

\section{References}

Avbovbo AA (1978) Tertiary lithostratigraphy of Niger Delta. AAPG Bull 62:237-241

Corredor F, Shaw JH, Bilotti F (2005) Structural styles in the deepwater fold and thrust belts of the Niger Delta. AAPG Bull 89(6):753-780

Deptuck ME, Steffens GS, Barton M, Pirmez C (2003) Architecture and evolution of upper fan channel-belts on the Niger Delta slope and in the Arabian sea. Mar Pet Geol 20:649-676

Doust H, Omatsola E (1990) Niger Delta. In: Edwards JD, Santogrossi PA (eds) Divergent/passive margin basins, vol 48. American Association of Petroleum Geologists Bulletin Memoir, Tulsa, pp 239-248

Evamy BD, Haremboure J, Kamerling P, Knaap WA, Molloy FA, Rowlands PH (1978) Hydrocarbon habitat of Tertiary Niger Delta. Am Assoc Pet Geol Bull 62:1-39

Ekwezor CM, Dakoru EM (1994) Northern delta depobelt portion of the AkataAgbada petroleum system, Niger delta, Nigeria. In: Magoon LB, Dow WG (eds) The petroleum system-from source to trap, vol 60. AAPG Memoir, Tulsa, pp 599-614

Haq BU, Hardenbol J, Vail PR (1988) Mesozoic and Cenozoic chronostratigraphy and eustatic cycles. In: Wilgus CK (ed) Sea level change: an integrated approach, special publication, vol 42. Society of Economic Paleontologists and Mineralogists, Chicago, pp 71-108

Nichols G (2009) Sedimentology and stratigraphy, 2nd edn. Wiley, Chichester

Nwachukwu JI, Chukwura PI (1986) Organic matter of Agbada Formation, Niger Delta, Nigeria. AAPG Bullettin 70:411-419

Prothero DR, Schwab F (2014) Sedimentary geology: an introduction to sedimentary rocks and stratigraphy, 3rd edn. W. H Freeman and Company, New York

Reijers TJA (2011) Stratigraphy and sedimentology of the Niger Delta. Geologos 17(3):133-162

Short KC, Stauble AJ (1967) Outline of geology of Niger Delta. Am Assoc Pet Geol Bull 51(3):761-799

Slatt RM, Jordan DW, Agostino AE, Gillespie RH (1992) Outcrop gamma-ray logging to improve understanding of subsurface well log correlation. Geol Soc Lond Spec Publ 65:3-19

Vail PR (1987) Seismic stratigraphy interpretation using sequence stratigraphy, part 1: seismic stratigraphy interpretation procedure. In: Bally AW (ed) Atlas of seismic stratigraphy. Studies in geology, vol 27, no 1. American Association of Petroleum Geologists, New York, pp 1-10

Vail PR, Mitchum RM Jr, Todd RG, Widmier JM, Thompson S III, Sangree JB, Bubb JN, Hatleid WG (1977) Seismic stratigraphy and global changes of sea level, part 2. In: Payton CE (ed) Seismic stratigraphy-application to hydrocarbon exploration, vol 26. American Association of Petroleum Geologist Memoir, Tulsa, pp 49-62

Van Wagoner JC, Posamentier HW, Mitchum RM, Vail PR, Sarg JF, Loutit TS, Hardenbol J (1988) An overview of sequence stratigraphy and key definitions. In: Wilgus CK, Hastings BS, Kendall CGSC, Posamentier HW, Ross CA, Van Wagoner JC (eds) Sea level changes - an integrated approach SEPM special publication, vol 42, pp 39-45

Publisher's Note Springer Nature remains neutral with regard to jurisdictional claims in published maps and institutional affiliations. 